\title{
Sensory Evaluation of Allium sativum - Cheddar Cheese in the Presence and Absence of Fish Collagen during Ripening and Refrigerated Storage
}

Amal Bakr Shori ${ }^{1 *}$, Ahmad Salihin Baba ${ }^{2}$ and Liew Sien Hoen Solear ${ }^{2}$

${ }^{1}$ Department of Biological Sciences, King Abdulaziz University, Jeddah 21589, Saudi Arabia

${ }^{2}$ Division of Biochemistry, Institute of Biological Sciences, University of Malaya, 50603 Kuala Lumpur, Malaysia

\begin{abstract}
The production of Allium sativum (AS) cheddar cheese in the presence and absence of fish collagen (FC) compared to plain cheese with/without FC was conducted to determine sensory evaluations during $0,14,30$, and 60 days of ripening. The evaluation system consists of seven parts; outer appearance, colour, texture, consistency of body, consistency of colour, flavour and aroma. Ripened cheeses were assessed by a sensory panels based on a 10-point system. The present results demonstrated that outer appearance of AS cheese in presence of FC showed the lowest score $(2.8 \pm 0.09)$ after 8 weeks of ripening. The color criteria of all fresh cheese samples reduced significantly $(p<0.05)$ at the end of ripening period. The highest flavor score of cheese samples was shown at week 2 of ripening for all cheese samples except of AS-cheese. AS-cheese in the presence and absence of FC registered lower aroma score than their respective control during the period of ripening. In conclusion, AS- and AS+FC-cheeses can be consumed within 2 to 4 weeks of storage for the best organoleptic properties.
\end{abstract}

Keywords: Cheddar cheese; Fish collagen; Allium sativum; Sensory evaluation

\section{Introduction}

Cheese is a kind of fermented milk-based food product, obtained by draining after coagulation of milk. It can also be regarded as "a consolidated curd of milk solids in which milk fat is entrapped by coagulated casein" [1]. Cheese ripening is a complex process in which characteristic aroma, flavour and texture of cheese develop during ripening by physico-chemical and biochemical changes. The sensory quality of cheese is an important criterion for consumers to making the purchasing decision whereas cheese type influenced consumers' preferences to a low extent [2]. The extents of growth of lactic acid bacteria during milk fermentation are associated with changes in sensory parameters and these are widely used to evaluate the final product of cheese [3].

Recently, development of dairy manufactures with new products and flavours has potential health benefits and could increase sales and consumers satisfaction [4-6]. Therefore, the preparation of cheeses may be beneficial by including other ingredients. Allium sativum (garlic) is a traditional medicinal plant possesses many healthful properties that are related to its bioactive compounds and have become recognized for its great value in the prevention of many diseases [7]. Collagen is made up of amino acids and forms the major protein in human body. It has a vital role in the growth, health and maintenance of muscles, tendons, skin, bones, ligaments, gum, eyes and blood vessels [8]. However, fish collagen has stimulation effect on collagen renewal and promoting the health of collagen. Besides, it can also be easily digested and completely soluble [9]. In the present study, sensory analysis of A. sativum cheddar cheese in the presence and absence of fish collagen compared to plain cheese with/without fish collagen (control) was evaluated during 60 days of ripening.

\section{Materials and Methods}

\section{Materials}

Fresh cow's milk was purchased from milk supplier and used on the day it was purchased. Garlic powder $\left(\mathrm{McCORMICK}^{\star}\right)$ was purchased from supermarket. Fish collagen powder was purchased from a local distributor. Probiotic bacteria mixture (Chris-Hansen,
Denmark) contains Lactobacillus acidophilus LA-5 (4 billion), Bifidobacterium lactis Bb-12 (4 billion), Lactobacillus casei LC-01 (1 billion), Streptococcus thermophilus Th-4 (1 billion) and L. bulgaricus in the ratio of 4:4:1:1:1. Rennet (Danisco Marcshall ${ }^{\mathrm{Tw}}$ M-50 Microbial) was used to coagulate the milk during cheese-making. Each tablet is $0.50 \mathrm{~g}$ (one tablet is able to clot $50 \mathrm{~L}$ of milk). The tablet contains microbial coagulant (M. meihi and/or M. Pussilus), salt, dicalcium phosphate, zinc stearate and cellulose microcrystalline.

\section{Water extraction of herb}

A. sativum ( $5 \mathrm{~g}$ ) was homogenized with $50 \mathrm{ml}$ distilled water by using a homogenizer. The mixture was left incubated in a water bath $\left(70^{\circ} \mathrm{C}\right)$ for $12-18$ hours. The herbal solution was then centrifuged $(2000$ $\mathrm{rpm}$ at $4^{\circ} \mathrm{C}, 15$ minutes) and the supernatant was used as water herbal extract in the experiment [6].

\section{Cheddar cheese preparation}

Fresh cow's milk $(1 \mathrm{~L})$ was poured in beaker placed into a hot water bath $\left(100^{\circ} \mathrm{C}\right)$. Milk was stirred slowly to facilitate an even heating to $72^{\circ} \mathrm{C}$ and the temperature was hold at $72^{\circ} \mathrm{C}$ for 15 seconds. The milk was then cooled down immediately to $32^{\circ} \mathrm{C}$ by placing the beaker into an ice bath. A sachet of probiotic bacteria as starter culture was added slowly in pre-warmed milk and the mixture was stirred thoroughly until the starter cultures were fully dissolved. The beaker was sealed with parafilm to ensure an anaerobic condition and incubated in the water bath at $41^{\circ} \mathrm{C}$ for an hour. Thereafter, $2 \mathrm{ml} / \mathrm{L}$ milk microbial rennet (one tablet of coagulant was dissolved properly in $100 \mathrm{ml}$ of distilled

*Corresponding author: Amal Shori B, Department of Biological Sciences, King Abdulaziz University, Jeddah, Saudi Arabia, E-mail: shori_7506@hotmail.com

Received August 29, 2016; Accepted September 15, 2016; Published September 20, 2016

Citation: Amal Shori B, Salihin BA, Sien Hoen SL (2016) Sensory Evaluation of Allium sativum - Cheddar Cheese in the Presence and Absence of Fish Collagen during Ripening and Refrigerated Storage. J Food Ind Microbiol 2: 115. doi:10.4172/2572-4134.1000115

Copyright: (c) 2016 Amal Shori B, et al. This is an open-access article distributed under the terms of the Creative Commons Attribution License, which permits unrestricted use, distribution, and reproduction in any medium, provided the original author and source are credited. 
Citation: Amal Shori B, Salihin BA, Sien Hoen SL (2016) Sensory Evaluation of Allium sativum - Cheddar Cheese in the Presence and Absence of Fish Collagen during Ripening and Refrigerated Storage. J Food Ind Microbiol 2: 115. doi:10.4172/2572-4134.1000115

Page 2 of 4

water which has been boiled) was added into the milk for curdling and the mixture was stirred evenly. The beaker was then placed in a water bath $\left(32^{\circ} \mathrm{C}\right)$ for 5.5 hours to allow coagulation to take place. The curd was then cut into grain size and gently stirred until the first flush of whey has left the curd particles. A. sativum water extract $(3 \mathrm{ml})$ and/ or fish collagen powder $(2.5 \mathrm{~g})$ were added into the coagulated milk and stirred thoroughly for an even distribution. The coagulated milk was poured into clean Muslin cloth to filter out the whey. The wrapped curds with cloth were then placed in a mould. The mould was then placed in a $2 \mathrm{~L}$ or $3 \mathrm{~L}$ beaker for pressing by placing dumbbell disks ( 2 $\mathrm{kg}$ ) onto the mould and the cheese was left to be pressed in a refrigerator (SHARP Deodorizer) at $8^{\circ} \mathrm{C}$ for 6 hours. Thereafter, the pressed cheese was taken out from the cloth and placed in a container containing 200 $\mathrm{mL}$ brine $(6 \% \mathrm{w} / \mathrm{v})$ for 8 hours at $8^{\circ} \mathrm{C}$. The cheese was unbrined and stored in a container with $4-5$ holes (each hole was $6 \mathrm{~cm}^{2}$ ). The holes were covered by a layer of tissue paper for aeration. The cheese was left in the refrigerator $\left(8^{\circ} \mathrm{C}\right)$ for ripening for a predetermined period $(0$, $14,30,60$ days). The porous container was changed daily for the first week, and then once every week for subsequent weeks until it achieved desired ripening duration to prevent the moisture from trapping in the container.

\section{Sensory evaluation}

Sensory criteria on cheeses were running during $0,2,4,8$ weeks of ripening. Ripened cheeses were assessed by untrained sensory panels comprised of ten members. The sensory evaluation system was a modification of Scandinavian and international 20-point system. The evaluation system consists of seven parts; outer appearance, colour, texture, consistency of body, consistency of colour, flavour and aroma. Each part was evaluated based on a 10-point system, whereby 9-10 was awarded as "Very Good", 7-8 as "Good", 5-6 as "Satisfactory", 3-4 as "Fairly Satisfactory", 1-2 as "Unsatisfactory" and 0 given as "Defective".

\section{Statistical analysis}

Data are presented as mean \pm S.E.M. All the data were used to perform a one-way ANOVA analysis of variance using the SPSS programme 12.0. Differences between the treatment and the control means were compared at the $5 \%$ of significance by least significant difference (LSD).

\section{Results}

\section{Sensory evaluation of cheese}

Outer appearance: There was no significant difference in outer appearance of fresh $\mathrm{P}$ and AS cheeses (7.9 and 7.8 respectively; 0 week; Table 1). However, the presence of FC increased $(\mathrm{p}<0.05)$ the outer

\begin{tabular}{|c|c|c|c|}
\hline Weeks & $\begin{array}{l}\text { Type of } \\
\text { cheese }\end{array}$ & $\begin{array}{c}\text { Outer } \\
\text { appearance of cheese } \\
\text { without FC }\end{array}$ & $\begin{array}{c}\text { Outer } \\
\text { appearance of cheese } \\
\text { with FC }\end{array}$ \\
\hline \multirow[t]{2}{*}{0} & \multirow{2}{*}{$\begin{array}{c}\mathrm{P} \\
\mathrm{AS}\end{array}$} & $7.9 \pm 0.12^{\mathrm{b}}$ & $8.3 \pm 0.06^{d}$ \\
\hline & & $7.8 \pm 0.03^{d}$ & $8.0 \pm 0.07^{d}$ \\
\hline \multirow[t]{2}{*}{2} & \multirow{2}{*}{$\begin{array}{c}\mathrm{P} \\
\mathrm{AS}\end{array}$} & $7.4 \pm 0.06^{b}$ & $7.0 \pm 0.06^{c}$ \\
\hline & & $6.7 \pm 0.09^{c}$ & $7.1 \pm 0.26^{c}$ \\
\hline \multirow[t]{2}{*}{4} & \multirow{2}{*}{$\begin{array}{c}\mathrm{P} \\
\mathrm{AS}\end{array}$} & $6.1 \pm 0.27^{a}$ & $6.4 \pm 0.07^{b}$ \\
\hline & & $5.5 \pm 0.15^{b}$ & $5.4 \pm 0.27^{b}$ \\
\hline \multirow[t]{2}{*}{8} & \multirow{2}{*}{$\begin{array}{c}\mathrm{P} \\
\mathrm{AS}\end{array}$} & $5.7 \pm 0.12^{\mathrm{a}}$ & $5.5 \pm 0.26^{a}$ \\
\hline & & $4.1 \pm 0.12^{\mathrm{a}}$ & $2.8 \pm 0.09^{a}$ \\
\hline
\end{tabular}

Values are means \pm standard error.

$a, b, c, d$ Means different superscripts within a column differ significant $(p<0.05)$.

Table 1: Changes of outer appearance of plain (P) and Allium sativum (AS) cheeses in the absence and presence of fish collagen (FC) during 8 weeks ripening. appearance of fresh $\mathrm{P}$ cheese (8.3) but not AS cheese (8.0). Outer appearance for all cheeses was decreased $(\mathrm{p}<0.05)$ during the ripening period. Furthermore, the outer appearance of AS cheese with or without FC reduced linearly and was significantly $(\mathrm{p}<0.05)$ lower than its respective control throughout ripening period (Table 1). Moreover, AS cheese with the addition of FC reduced more drastic (8.0-2.8; $\mathrm{p}<0.05)$ than without FC $(7.8-4.1)$ through the ripening period. On the other hand, $\mathrm{P}$ cheese in both presence and absence of FC had almost similar scores ranged from 8 to 6 (Table 1).

Color: The color scores of $\mathrm{P}$ and AS in the presence and absence of FC were the highest in 0 week (Table 2). All types of cheese decreased significantly $(\mathrm{p}<0.05 \%)$ during the eight weeks ripening except for $\mathrm{P}$ cheese without FC on week 2 and 8 ( $p>0.05 \%)$. There was no difference in color for $\mathrm{P}$ and AS cheeses either with FC (8.3-5.1 and 7.7-3.1 respectively) or without FC (8.1-5.8 and 7.9-4.1 respectively).

Texture: The texture of $\mathrm{P}$ and AS cheeses showed similar scores (8) during the first weeks (Table 3). However, this followed by significant reduction $(\mathrm{p}<0.05)$ to $5.4 \pm 0.03$ and $2.1 \pm 0.06$ for $\mathrm{P}$ and AS cheeses respectively after 8 weeks. In addition, $\mathrm{P}$ cheese with $\mathrm{FC}$ reduced $(\mathrm{p}<0.05)$ from $7.9 \pm 0.12$ to $5.2 \pm 0.26$ after 8 weeks. Conversely, AS cheese with FC increased slightly ( $p>0.05)$ from $7.6 \pm 0.12$ to $7.8 \pm 0.15$ after 2 weeks before sharply decreased $(\mathrm{p}<0.05)$ to $1.9 \pm 0.09$ in week 8 .

Consistency of body and consistency of color: The consistency of body and consistency of color scored the best on week 0 for all types of cheese (8.0-7.0; Table 4). In addition, both $\mathrm{P}$ and AS cheese showed a significant decreasing $(\mathrm{p}<0.05)$ in consistency of body and consistency of color (8-5 and 7-2 respectively) throughout 8 weeks ripening. The same trend was observed with the addition of FC, where consistency of body and consistency of color were significantly decreased in

\begin{tabular}{|c|c|c|c|}
\hline Weeks & $\begin{array}{l}\text { Type of } \\
\text { cheese }\end{array}$ & $\begin{array}{c}\text { Outer } \\
\text { appearance of cheese } \\
\text { without FC }\end{array}$ & $\begin{array}{l}\text { Outer } \\
\text { appearance of cheese } \\
\text { with FC }\end{array}$ \\
\hline \multirow[t]{2}{*}{0} & \multirow{2}{*}{$\begin{array}{c}\mathrm{P} \\
\mathrm{AS}\end{array}$} & $8.1 \pm 0.27^{b}$ & $8.3 \pm 0.17^{d}$ \\
\hline & & $7.9 \pm 0.15^{d}$ & $7.7 \pm 0.09^{d}$ \\
\hline \multirow[t]{2}{*}{2} & \multirow{2}{*}{$\begin{array}{c}\mathrm{P} \\
\mathrm{AS}\end{array}$} & $7.6 \pm 0.23^{b}$ & $6.7 \pm 0.20^{c}$ \\
\hline & & $6.4 \pm 0.10^{c}$ & $6.7 \pm 0.22^{c}$ \\
\hline \multirow[t]{2}{*}{4} & \multirow{2}{*}{$\begin{array}{l}\mathrm{P} \\
\mathrm{AS}\end{array}$} & $6.2 \pm 0.10^{\mathrm{a}}$ & $5.9 \pm 0.12^{b}$ \\
\hline & & $4.8 \pm 0.09^{b}$ & $4.7 \pm 0.12^{\mathrm{b}}$ \\
\hline \multirow[t]{2}{*}{8} & \multirow{2}{*}{$\begin{array}{c}\mathrm{P} \\
\mathrm{AS}\end{array}$} & $5.8 \pm 0.07^{a}$ & $5.1 \pm 0.09^{a}$ \\
\hline & & $4.1 \pm 0.06^{a}$ & $3.1 \pm 0.10^{a}$ \\
\hline
\end{tabular}

Values are means \pm standard error.

$a, b, c, d$ Means different superscripts within a column differ significant $(p<0.05)$.

Table 2: Changes of color of plain $(P)$ and Allium sativum (AS) cheeses in the absence and presence of fish collagen (FC) during 8 weeks ripening.

\begin{tabular}{|c|c|c|c|}
\hline Weeks & $\begin{array}{l}\text { Type of } \\
\text { cheese }\end{array}$ & $\begin{array}{c}\text { Outer } \\
\text { appearance of cheese } \\
\text { without FC }\end{array}$ & $\begin{array}{c}\text { Outer } \\
\text { appearance of cheese } \\
\text { with FC }\end{array}$ \\
\hline \multirow[t]{2}{*}{0} & \multirow{2}{*}{$\begin{array}{c}\mathrm{P} \\
\mathrm{AS}\end{array}$} & $7.8 \pm 0.12^{\mathrm{c}}$ & $7.9 \pm 0.12^{c}$ \\
\hline & & $7.7 \pm 0.03^{d}$ & $7.6 \pm 0.12^{c}$ \\
\hline \multirow[t]{2}{*}{2} & \multirow{2}{*}{$\begin{array}{c}\mathrm{P} \\
\mathrm{AS}\end{array}$} & $7.8 \pm 0.06^{c}$ & $6.8 \pm 0.20^{b}$ \\
\hline & & $5.6 \pm 0.09^{c}$ & $7.8 \pm 0.15^{c}$ \\
\hline \multirow[t]{2}{*}{4} & \multirow{2}{*}{$\begin{array}{c}\mathrm{P} \\
\mathrm{AS}\end{array}$} & $6.2 \pm 0.07^{b}$ & $5.2 \pm 0.13^{a}$ \\
\hline & & $3.2 \pm 0.03^{b}$ & $3.1 \pm 0.26^{b}$ \\
\hline \multirow[t]{2}{*}{8} & \multirow{2}{*}{$\begin{array}{c}P \\
\text { AS }\end{array}$} & $5.4 \pm 0.03^{a}$ & $5.2 \pm 0.26^{a}$ \\
\hline & & $2.1 \pm 0.06^{\mathrm{a}}$ & $1.9 \pm 0.09^{a}$ \\
\hline
\end{tabular}

Values are means \pm standard error.

$a, b, c, d$ Means different superscripts within a column differ significant $(p<0.05)$.

Table 3: Changes of texture of plain (P) and Allium sativum (AS) cheeses in the absence and presence of fish collagen (FC) during 8 weeks ripening. 
Citation: Amal Shori B, Salihin BA, Sien Hoen SL (2016) Sensory Evaluation of Allium sativum - Cheddar Cheese in the Presence and Absence of Fish Collagen during Ripening and Refrigerated Storage. J Food Ind Microbiol 2: 115. doi:10.4172/2572-4134.1000115

Page 3 of 4

both $\mathrm{P}$ (8.0-4.7 and 8.0-4.8 respectively) and AS (6.8-2.0 and 7.5-2.5 respectively) cheeses after 8 weeks (Table 4 ).

Flavor: The highest flavor score (7.0) was shown in week 2 of ripening for all types of cheese except of AS cheese that showed the highest score (5.8 \pm 0.33$)$ in 0 week of ripening (Table 5). In addition, $\mathrm{P}$ cheese in the presence and absence of FC showed a satisfactory flavor (5-6) during 8 weeks of ripening. However, the flavor score of AS cheese with or without FC gradually decreased to about 3 after 8 weeks of ripening.

Aroma: There were significant reduction $(\mathrm{p}<0.05)$ in aroma of $\mathrm{P}$ cheese ( $6.7 \pm 0.06$ to $5.3 \pm 0.09)$ and AS cheese ( $5.7 \pm 0.12$ to $2.3 \pm 0.09)$ during 8 weeks of ripening (Table 6). The presence of FC decreased aroma in fresh AS- $(5.5 \pm 0.12)$ but not $\mathrm{P}-(7.3 \pm 0.15)$ cheese. This followed by significant reduction to $2.3 \pm 0.06$ and $4.4 \pm 0.06$ for AS and $\mathrm{P}$ cheeses respectively after 8 weeks ripening.

\section{Discussions}

Cheese ripening is the important part of sensory evaluation of cheese. Proteolysis plays a critical role in determining the typical sensory characteristics and represents a significant indicator of quality [10]. It is also the major event in the ripening of hard and semi hard cheeses and contributes to the flavor and texture development in the cheese [11]. The proteolytic products thus contribute directly to the basic taste of the cheese, cheese flavor and precursors for the other catabolic reactions, giving rise to volatile aroma compounds [12]

The evaluation of outer appearance is greatly influenced by the formation of the rind. All the fresh cheeses without rind are given higher scores than those eight weeks cheese with thick rind. The addition of A. sativum has given a less favor appearance to the cheese. This is because losing of water throughout ripening due to the high moisture content in A. sativum cheese when compared to plain cheese. In addition, the outer appearance and color deteriorates throughout ripening probably due to the oxidation of the herbs occurring during storage in the refrigerator. When oxygen comes in contact to the cheese, it contributes to the oxidation of fats and the growth of undesirable microorganisms [13].

The texture of cheese depends upon the cheese composition and the extent of biochemical changes during ripening [14,15] Changes in the texture of cheese during ripening are known to be a major factor contributing to cheese quality and acceptability [11]. The water content, homogenecity of the cheese, distribution of herbs and the phytochemical effects are all the factors contributed to the texture quality. Generally, values for these parameters should increase gradually during the eight weeks of ripening time depended on the moisture loss and affected by the proteolysis. However, texture for all cheeses decreased in scores throughout ripening because the cheeses getting too hard due to loss of water. The increase in hardness during the eight weeks of ripening is related to decreasing moisture which acts as plasticisers in the protein matrix, thereby making it less elastic and more susceptible to fracture upon compression [14]

During ripening, the body and color of cheese were not consistent. The cheese might be slimy in the first few weeks of ripening, due to water evaporation from the body to surface, or water trapped in the container during storage. The rind of cheese also affected the consistency. This resulted the color of cheese became darker from the surface to inner part. The distribution of herbs although even in the cheese, might give uneven color due to its discoloration in response to level of moisture from the surface to the center of the cheese [14]. There was no significant difference in both consistency of body and color between cheeses with and without fish collagen.

\begin{tabular}{|c|c|c|c|c|c|}
\hline Weeks & $\begin{array}{l}\text { Type of } \\
\text { Cheese }\end{array}$ & $\begin{array}{c}\text { Consistency } \\
\text { of body of cheese without FC }\end{array}$ & $\begin{array}{l}\text { Consistency } \\
\text { of color of cheese without FC }\end{array}$ & $\begin{array}{c}\text { Consistency } \\
\text { of body of cheese with FC }\end{array}$ & $\begin{array}{c}\text { Consistency } \\
\text { of color of cheese with FC }\end{array}$ \\
\hline \multirow[t]{2}{*}{0} & $\mathrm{P}$ & $8.0 \pm 0.18^{d}$ & $7.8 \pm 0.03^{d}$ & $8.0 \pm 0.06^{c}$ & $8.0 \pm 0.03^{c}$ \\
\hline & AS & $7.1 \pm 0.15^{d}$ & $7.4 \pm 0.09^{d}$ & $6.8 \pm 0.33^{c}$ & $7.5 \pm 0.15^{c}$ \\
\hline \multirow[t]{2}{*}{2} & $P$ & $6.9 \pm 0.09^{c}$ & $6.4 \pm 0.03^{c}$ & $7.0 \pm 0.09^{b}$ & $6.9 \pm 0.09^{b}$ \\
\hline & AS & $5.6 \pm 0.18^{c}$ & $6.1 \pm 0.19^{c}$ & $7.0 \pm 0.30^{c}$ & $6.6 \pm 0.26^{b}$ \\
\hline \multirow[t]{2}{*}{4} & $\mathrm{P}$ & $5.6 \pm 0.12^{b}$ & $6.0 \pm 0.03^{b}$ & $5.0 \pm 0.06^{a}$ & $5.1 \pm 0.32^{\mathrm{a}}$ \\
\hline & AS & $3.3 \pm 0.03^{b}$ & $3.7 \pm 0.06^{b}$ & $3.2 \pm 0.10^{\mathrm{b}}$ & $3.2 \pm 0.39^{\mathrm{a}}$ \\
\hline \multirow[t]{2}{*}{8} & $P$ & $5.1 \pm 0.10^{a}$ & $5.4 \pm 0.09 a$ & $4.7 \pm 0.15^{\mathrm{a}}$ & $4.8 \pm 0.30^{\mathrm{a}}$ \\
\hline & AS & $2.1 \pm 0.10^{a}$ & $2.4 \pm 0.17^{a}$ & $2.0 \pm 0.21^{a}$ & $2.5 \pm 0.07^{a}$ \\
\hline
\end{tabular}

Values are means \pm standard error.

$a, b, c, d$ Means different superscripts within a column differ significant $(p<0.05)$.

Table 4: Changes of consistency of body and consistency of color of plain (P) and Allium sativum (AS) cheeses in the absence and presence of fish collagen (FC) during 8 weeks ripening.

\begin{tabular}{|c|c|c|c|}
\hline Weeks & $\begin{array}{l}\text { Type of } \\
\text { cheese }\end{array}$ & $\begin{array}{c}\text { Outer } \\
\text { appearance of cheese } \\
\text { without FC }\end{array}$ & $\begin{array}{l}\text { Outer } \\
\text { appearance of cheese } \\
\text { with FC }\end{array}$ \\
\hline \multirow[t]{2}{*}{0} & \multirow{2}{*}{$\begin{array}{c}\mathrm{P} \\
\mathrm{AS}\end{array}$} & $6.4 \pm 0.09^{\mathrm{bc}}$ & $5.6 \pm 0.17^{\mathrm{b}}$ \\
\hline & & $5.8 \pm 0.33^{c}$ & $6.0 \pm 0.26^{b}$ \\
\hline \multirow[t]{2}{*}{2} & \multirow{2}{*}{$\begin{array}{c}P \\
\text { AS }\end{array}$} & $6.7 \pm 0.15^{c}$ & $6.6 \pm 0.06^{c}$ \\
\hline & & $5.3 \pm 0.03^{c}$ & $6.5 \pm 0.23^{b}$ \\
\hline \multirow[t]{2}{*}{4} & \multirow{2}{*}{$\begin{array}{l}\mathrm{P} \\
\mathrm{AS}\end{array}$} & $5.9 \pm 0.19^{b}$ & $5.2 \pm 0.19^{b}$ \\
\hline & & $3.7 \pm 0.12^{b}$ & $3.1 \pm 0.19^{a}$ \\
\hline \multirow[t]{2}{*}{8} & \multirow{2}{*}{$\begin{array}{c}\mathrm{P} \\
\mathrm{AS}\end{array}$} & $5.5 \pm 0.03^{a}$ & $4.5 \pm 0.15^{\mathrm{a}}$ \\
\hline & & $2.8 \pm 0.09^{a}$ & $2.6 \pm 0.10^{a}$ \\
\hline
\end{tabular}

Values are means \pm standard error.

$a, b, c, d$ Means different superscripts within a column differ significant $(p<0.05)$.

Table 5: Changes of flavor of plain $(P)$ and Allium sativum (AS) cheeses in the absence and presence of fish collagen (FC) during 8 weeks ripening.

\begin{tabular}{|c|c|c|c|}
\hline Weeks & $\begin{array}{c}\text { Type of } \\
\text { cheese }\end{array}$ & $\begin{array}{c}\text { Outer } \\
\text { appearance of cheese } \\
\text { without FC }\end{array}$ & $\begin{array}{c}\text { Outer } \\
\text { appearance of cheese } \\
\text { with FC }\end{array}$ \\
\hline 0 & P & $6.7 \pm 0.06^{\mathrm{c}}$ & $7.3 \pm 0.15 \mathrm{~d}$ \\
\cline { 3 - 4 } & AS & $5.7 \pm 0.12^{\mathrm{d}}$ & $5.5 \pm 0.12^{\mathrm{c}}$ \\
\hline 2 & $\mathrm{P}$ & $6.6 \pm 0.23^{\mathrm{c}}$ & $6.5 \pm 0.10^{\mathrm{c}}$ \\
\hline \multirow{2}{*}{4} & AS & $4.9 \pm 0.20^{\mathrm{c}}$ & $5.0 \pm 0.22^{\mathrm{b}}$ \\
\hline \multirow{2}{*}{8} & $\mathrm{P}$ & $5.8 \pm 0.17^{\mathrm{b}}$ & $5.2 \pm 0.09^{\mathrm{b}}$ \\
\hline \multirow{2}{*}{8} & AS & $2.9 \pm 0.06^{\mathrm{b}}$ & $2.3 \pm 0.06^{\mathrm{a}}$ \\
\hline & AS & $5.3 \pm 0.09^{\mathrm{a}}$ & $4.4 \pm 0.06^{\mathrm{a}}$ \\
\cline { 3 - 4 } & AS & $2.3 \pm 0.09^{\mathrm{a}}$ & $1.9 \pm 0.06^{\mathrm{a}}$ \\
\hline
\end{tabular}

Values are means \pm standard error.

$a, b, c, d M e a n s$ different superscripts within a column differ significant $(p<0.05)$.

Table 6: Changes of aroma of plain (P) and Allium sativum (AS) cheeses in the absence and presence of fish collagen (FC) during 8 weeks ripening. 
Citation: Amal Shori B, Salihin BA, Sien Hoen SL (2016) Sensory Evaluation of Allium sativum - Cheddar Cheese in the Presence and Absence of Fish Collagen during Ripening and Refrigerated Storage. J Food Ind Microbiol 2: 115. doi:10.4172/2572-4134.1000115

Page 4 of 4

Catabolic reactions and side-chain modification of amino acids yield keto acids, ammonia, amines, aldehydes, acids and alcohol, which are essential contributors to cheese flavor and aroma [16-18]. The fat content in of milk contributes to the flavor of cheese. Lipolysis plays an essential role in the sensory properties of cheese; some free fatty acids (FFAs) have been shown to contribute directly to the aroma characteristics of many types of cheese, or indirectly as precursors of aroma components [19]. The lipid metabolites include fatty acids esters, aldehyde, alcohols, ketones and sulphur compounds have been reported to be important contributors to the final taste and aroma of cheese [20].

Longer ripening periods may enhance the flavor and aroma of cheeses. However, both cheeses with and without fish collagen decreased in scores in those evaluations due to the bitter taste in cheeses in the eight weeks of storage. Proteolysis may contribute directly to the off-flavor (e.g., bitterness) after long period of cheese ripening [21]. Acetate produced by starter bacteria or probiotic adjunct such as Lactobacillus and Bifidobacterium from lactose or citrate or amino acid is considered to contribute to cheese flavor but in high concentrations may also cause off-flavors [10]. Moreover, the scores of aroma in $A$. sativum cheese lower than control due to the strong odor. Allicin is mainly responsible for garlic's pungent odor. It is formed by the action of the enzyme alliinase on the compound alliin [22]. In addition, treatment with fish collagen deteriorates the aroma of the cheese due to the smell after long period of storage [23].

\section{Conclusion}

The present results established that outer appearance of AS cheese in presence of FC showed the lowest score during ripening period. Texture, consistency of body and consistency of color for all cheese samples showed decreased over the storage period. The highest flavor score of cheese samples was shown on week 2 of ripening for all cheese samples except of AS-cheese. Aroma score was low in AS-cheese in both presence and absence of FC. The sensory evaluation revealed that AScheese in the presence and absence of FC had low organoleptic qualities compared to the conventional cheese with/without FC. Based on the present results, AS- and AS+FC-cheeses can be consumed within 2 to 4 weeks of storage for the best organoleptic properties.

\section{References}

1. Adams MR, Moss MO (2002) Food Microbiology. RSC Publishing, UK.

2. Majchrzak D, Lahm B Durrschmid K (2010) Conventional and probiotic yogurts differ in sensory properties but not in consumers' preferences. J Sensory Stud 25: 431-446.

3. Donkor ON, Henriksson A, Singh TK, Vasiljevic T, Shah NP (2007) ACEinhibitory activity of probiotic yoghurt. Int Dairy J 17: 1321-1331.

4. Shori AB, Baba AS (2011) Cinnamomum verum improved the functional properties of bio-yogurts made from camel and cow milks. J Saudi Soci Agri Sci 10: 101-107.

5. Shori AB, Baba AS (2013) Antioxidant activity and inhibition of key enzymes linked to type-2diabetes and hypertension by Azadirachta indica-yogurt. J Saudi Chem Soci 17: 295-301.

6. Shori AB, Baba AS (2014) Comparative antioxidant activity, proteolysis and in vitro $\alpha$-amylase and $\alpha$-glucosidase inhibition of Allium sativum-yogurts made from cow and camel milk. J Saudi Chem Soci 18: 456-463.
7. Silagy CA, Neil AW (1994) A meta-analysis of the effect of garlic on blood pressure. J Hypertens 12: 463-8.

8. Hwang JH, Mizuta S, Yogoyama Y, Yoshinaka R (2007) Purification and characterization of molecular species of collagen in the skin of skate (Raja kenojei). Food Chem 100: 921-925.

9. Koyama Y, Sakashita A, Kuwaba K, Kusubata M (2006) Effects of oral ingestion of collagen peptide on the skin. Fragr J 34: 85-82.

10. Fox PF, McSweeney PLH (1996) Biochemical pathways for the production of flavour compounds in cheeses during ripening: a review. Lait 80: 293-324.

11. Attaie R (2005) Effects of aging on rheological and proteolytic properties of goat milk Jack Cheese produced according to cow milk procedures. Small Rumin. Res 57: 19-29.

12. Fox PF, Wallace J (1997) Biochemistry of cheese ripening. Chapman \& Hall, UK.

13. Robertson LG (1993) Food packaging: principles and practice.

14. Fox PF, Guinee TP, Cogan TM, McSweeney PLH (200) Fundamentals of Cheese Science. Aspen Publishers Inc, Neywork.

15. Lawrence RC, Heap HA, Gilles J (2004) A controlled approach to cheese technology. J Dairy Sci 67: 1632-1645.

16. Esriche I, Serra JA, Guardiola V, Mulet A (1999) Composition of Medium Volatibility (Simultaneous Distillation Extraction-SDE) Aromatic Fraction of Pressed, Uncooked Paste Cheese (Mahon Cheese). J Food Compos Anal 12 : 63-69.

17. Irygoyen A, Ortigosa M, Juansaras I, Oneca M, Torre P (2007) Influence of an adjunct culture of Lactobacillus on the free amino acids and volatile compound in a Roncal-type ewe's-milk cheese. Food Chem 100: 71-80.

18. Hannon JA, Kilcawley KN, Wilkinson MG, Delahunty CM, Beresford TP (2007) Flavour Precoursor development in Cheddar cheese due to lactococcal starters and the presence and lyses of Lactobacillus helveticus. Int Dairy J 17: 316-327.

19. Poveda JM, Cabezas L (2006) Free fatty acid composition of regionallyproduced Spanish goat cheese and relationship with sensory characteristics. Food Chem 95: 301-311.

20. Bosset JO, Gauch R (1993) Comparison of the volatile flavours compounds of six European "AOC" cheeses by using a new dynamic headspace GS-MS method. Int Dairy J 3: 359-377.

21. Sousa MJ, Ardo Y, McSweeneya PLH (2001) Advances in the study of proteolysis during cheese ripening. Int Dairy J 11: 327-345.

22. Bever BO, Zahnd GR (1979) Plants with oral hypoglycemic action. Quarterly $J$ Crude Drug Res 17: 139-96.

23. Shori AB, Baba AS, Chuah PF (2013) The Effects of Fish Collagen on the Proteolysis of Milk Proteins in Allium sativum-Yogurt. Taiwan Inst Chem Eng 44: 701-706. 